\title{
GYÜMÖLCSFELDOLGOZÓ ÜZEM LÉTESÍTÉSÉNEK PÉNZÜGYI ELŐKÉSZÜLETEI
}

\author{
Zsótér Brigitta - Bagi Bence
}

\begin{abstract}
Absztrakt: Egy Bács-Kiskun megyei gyümölcsfeldolgozó üzem létesítésének pénzügyi tervezését végeztük el. Már megvalósult, hasonló jellegü üzemek látogatását és a befektetőkkel készített interjúkat követően megterveztük a saját beruházásunkat. A legnagyobb üzemmérettel rendelkező vállalat 50 partnerrel rendelkezik, akik megközelítőleg 1000 hektáron gazdálkodnak. Főként bodza és almalé sürítményt állítanak elő. A pályázati lehetőségeket figyelembe véve számoltuk ki a pénzügyi elökalkulációinkat. Két forgatókönyvet készítettünk. Az egyiknél figyelembe vettük a rendelkezésre álló pályázati forrásokat, a másikat pedig kizárólag saját tőkéből finanszírozva terveztük meg. Mindkét szcenárió esetén alkalmaztuk a DPB, NPV, IRR és a PI mutatókat. Természetesen a pályázat által finanszírozott forgatókönyv eredményei a kedvezőbbek, tehát ezt érdemesebb megvalósítanunk a jövőben.
\end{abstract}

\begin{abstract}
In our research work we created a financial plan for a fruit processing facility located in the district of Bacs-Kiskun, Hungary. Building our business plan was based on consulting with investors and visiting several fruit processing plants. The biggest manufactory has a number of 50 partners who farm about 1.000 hectares of fruit. Mainly produces elderberry and apple concentrate. The estimate was made regarding opportunities for EU fundings. Scenario planning allowed us to generate a first set of forecasts, identify the key signposts that distinguish one scenario versus another. The first one included the current EU funding, the second one was financed completely with our own resources without leverage.

Calculation included Discounted Payback Period (DPP), Net Present Value (NPV), Internal Rate of Return (IRR) and Profitability Index (PI). The EU funded scenario seemed to be more beneficial, it is worth implementing.
\end{abstract}

Kulcsszavak: gyümölcsfeldolgozó üzem, pénzügyi elökalkulációk, beruházás, tervezés

Keywords: fruit processing facility, financial estimates, investment, planning

\section{Bevezetés}

Kiemelkedő jelentőségü gazdasági ágazat az élelmiszer-termelés és feldolgozás a világ valamennyi országában. Földünk növekvő népességének élelmiszerigénye hatalmas léptékben növekszik, az élelmiszer-elöállítás ökológiai korlátai viszont adottak (Medina, 2005).

Az élelmiszerek feldolgozásában és elöállításában résztvevők mind versenyben állnak egymással. A magyar termelőknek és vállalatoknak is ebben a globális versenyben kell megállni a helyüket hazai, valamint az Európai Unió egységes piacán és a világpiacon egyaránt (Kormos, 2017). Természetesen ezen vállalatok esetében is figyelembe kell venni a szigorú fogyasztóvédelmi elöírásokat (Gál, 2009) és a fenntarthatósággal kapcsolatos igényeket (Turi et al., 2014).

A versenyképesség megteremtésének alapja, hogy az itt élő gazdálkodókat, üzemvezetőket és szakmunkásaikat képessé kell tenni, hogy élni tudjanak a lehetőségeikkel és ezzel magasabb szintre emelhessék életszínvonalukat, hosszú távon javítsák az életminőségüket (Kis, 2014).

Az ország alapvető érdeke, hogy az élelmiszergazdaság kiemelkedő adottságait kihasználva, versenyképességét megteremtve, stabilan ki tudja elégíteni a hazai 
élelmiszerszükségletet, és a határon túl is eredményesen tudja értékesíteni termékeit, ezáltal hozzájárulva a gazdaság fejlődéséhez (Andrási et al., 2009). Ez az érdek különösen annak figyelembevételével fontos, hogy Magyarországon az élelmiszergazdaság a nemzetgazdaság egészén belül sokkal nagyobb súlyú a termelést, az exportot és a foglalkoztatást tekintve, mint más hasonló gazdasági fejlettségü országokban (Kanyó et al., 2008).

Ezt bizonyítja az is, hogy a nemzetgazdasági beruházások több, mint negyedét jelentő feldolgozóipar fejlesztései, 2018 IV. negyedévében a fejlesztések volumene 17\%-kal meghaladta az előző év azonos időszaki mutatóit.

Családunk valamennyi tagja gyümölcstermesztéssel foglalkozik, így személyesen is tapasztaljuk, hogy a versenyképesség megőrzéséhez elengedhetetlenek a folyamatos fejlesztések, a megtermelt gyümölcsök feldolgozása és a korszerü technológiák alkalmazása.

Gyümölcsfeldolgozó üzemek látogatása során a tulajdonosokkal készített interjúkra alapozva megterveztük a saját beruházásunkat. Kalkulációink elvégzését segítették a különböző méretü feldolgozó üzemek által nyújtott információk, tervek, illetve könyvelt dokumentumok. A legnagyobb üzemmérettel rendelkező vállalat 50 partnerrel rendelkezik, akik körülbelül 1000 hektáron gazdálkodnak. Föként fekete bodza és almalé sürítményt állítanak elö.

Egyelöre önerőből történő finanszírozással végeztük el a pénzügyi előkalkulációinkat, de a jövőben EU pályázati forrás bevonásával a „VP Mezőgazdasági termékek értéknövelése a feldolgozásban" címü, 50\%-os intenzitású pályázati felhívással is számolni fogunk. A két forgatókönyvet összehasonlítjuk és többek között megállapítjuk azt is, hogy melyik finanszírozási formával térül meg hamarabb a beruházásunk, melyik szcenáriót éri meg jobban megvalósítani.

A tervezett beruházás várható pénzigénye bruttó $136770000 \mathrm{Ft}$.

A befektetők által elvárt éves hozam: 6\%. Várható hasznos élettartam: 50 év.

\section{Anyag és módszer}

Kalkulációink elvégzéséhez a beruházási tervünkhöz hasonló tevékenységet folytató élelmiszer feldolgozó üzemeket látogattunk meg 2019. június és augusztus közötti időszakban. A tulajdonosok kérésére anonim módon hivatkozunk rájuk, mint egy Bács-Kiskun megyei gyümölcsfeldolgozó üzemre. Elözetes elképzeléseinkhez a legjobban illeszkedő vállalat közel 50 partnerrel rendelkezik, akikkel egész évben tartják a kapcsolatot és a megtermelt áruikra felvásárlási kötelezettséggel bíró szerződéssel rendelkeznek. Az üzemvezetővel készített interjú során fény derült, hogy a legintenzívebb időszak egyértelmüen a betakarítás körüli (július-szeptember). Ilyenkor az üzem maximálisan kihasználja a rendelkezésre álló feldolgozó kapacitását és az állandó munkavállalói mellé jelentős számú, átlagosan körülbelül plusz 50 fövel bővíti alkalmazottainak számát. Az előállított sürítményeket belföldön és külföldön is egyaránt értékesítik, körülbelül 30-70\% arányban a jól kialakított partnerkapcsolataiknak köszönhetöen.

További kérdéseinkre, amik a gazdaságossági számításainkhoz nélkülözhetetlenek, a gazdasági vezető és a könyvelésen dolgozó munkatársak álltak 
rendelkezésünkre. Beruházás gazdaságossági kalkulációkat alkalmaztuk munkánk során, többek között a nettó jelenértéket (NPV), a belső megtérülési rátát (IRR), a megtérülési időt (PB), a diszkontált megtérülési időt (DPB) és a jövedelmezőségi indexet (PI) (Bélyácz, 2007). Továbbá meg fogjuk vizsgálni a jövőben a beruházás kockázati szempontjait és összehasonlítjuk a beruházás sikerességét két eltérő finanszírozási móddal: önerőből, illetve pályázati forrás bevonásával. A támogatás intenzitása várhatóan $50 \%$. A befektetők által elvárt éves hozam $6 \%$.

\section{Eredmények és értékelésük}

A következő képen a tervezett gyümölcsfeldolgozó üzem tervrajza látható (1. ábra)

\section{1. ábra: A tervezett feldolgozó üzem}

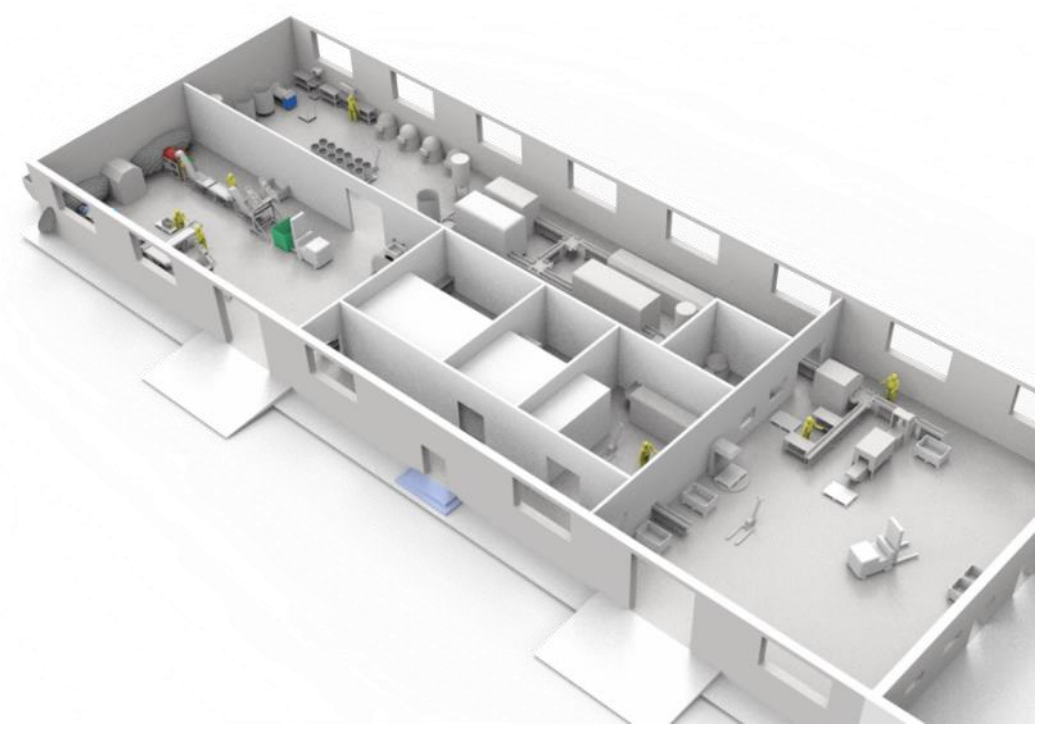

Forrás: Egyik vállalat által biztosított tervrajz

Az alábbi számításainkból jól kivehető, hogy önerőből megvalósítva milyen jövőbeli eredményeket várhatunk a beruházástól. Az 1. táblázat mutatja a cash flow számításunkat. Minden év végén a várható müködési pénzáram 27894000 Ft.

\section{1. táblázat: Cash flow (müködési pénzáram) számítás}

\begin{tabular}{|l|r|}
\hline + Árbevétel & $330000000 \mathrm{Ft}$ \\
\hline - Folyó müködési költségek & $300000000 \mathrm{Ft}$ \\
\hline - Értékcsökkenési leírás (É.CS.) & $6600000 \mathrm{Ft}$ \\
\hline Adózás elötti eredmény (EBIT) & $23400000 \mathrm{Ft}$ \\
\hline - Társasági adó (TA 9\%) & $2160000 \mathrm{Ft}$ \\
\hline Adózás utáni eredmény & $21294000 \mathrm{Ft}$ \\
\hline + Értékcsökkenési leírás (É.CS.) & $6600000 \mathrm{Ft}$ \\
\hline Müködési pénzáram (Cash flow) & $\mathbf{2 7 8 9 4 0 0 0 ~ F t ~}$ \\
\hline
\end{tabular}

Forrás: Saját előkalkuláció eredményei, a szerzők szerkesztése 
Gazdaságossági számításaink során kiszámoltuk a belső megtérülési rátát (1), A jövedelmezőségi indexet (2), a diszkontált megtérülési időt (3) és a nettó jelentértéket (4).

- Belső megtérülési ráta (IRR):

$$
\begin{gathered}
-\mathrm{C}_{0}+\sum_{\mathrm{t}=1}^{\mathrm{n}} \frac{\mathrm{C}_{\mathrm{t}}}{(1+\mathrm{IRR})^{\mathrm{t}}}=0 \\
I R R=\frac{\text { Kezdó tókebefektetés }}{\text { Éves nettó pénzáram }}=\frac{136.770 .000 \mathrm{Ft}}{9.346 .186 \mathrm{Ft}}=14,63 \\
\text { PVIFA }(r \%, 50 \text { é } v)=14,63 \\
\text { IRR }=9 \%
\end{gathered}
$$

- Jövedelmezőségi index (PI):

$$
\mathrm{PI}=\frac{\sum_{\mathrm{t}=1}^{\mathrm{n}} \frac{\mathrm{C}_{\mathrm{t}}}{(1+\mathrm{r})^{\mathrm{t}}}}{\mathrm{C}_{0}}=\frac{166.034 .994 F t}{136.770 .000 F t}=1,21
$$

- Diszkontált megtérülési idő (DPB):

$$
\begin{array}{r}
\mathrm{DPB}=\frac{\text { Kezdó tókebefektetés }}{\text { Éves nettó pénzáram }}=\frac{136.770 .000 \mathrm{Ft}}{9.346 .186 \mathrm{Ft}}=14,63 \\
\text { PVIFA }(6 \%, \mathrm{t} \text { év })=14,63 \\
\mathrm{DPB}=24 \text { év }
\end{array}
$$

- Nettó jelenérték (NPV):

$$
\mathrm{NPV}=-\mathrm{C}_{0}+\sum_{\mathrm{t}=1}^{\mathrm{n}} \frac{\mathrm{C}_{\mathrm{t}}}{(1+\mathrm{r})^{\mathrm{t}}}=29264999 \mathrm{Ft} \text { (4) }
$$

A 2. táblázat segítségével foglaltuk össze a kapott eredményeket.

2. táblázat: A kalkulációk során kapott eredmények összesítése

\begin{tabular}{|ccc|}
\hline $\begin{array}{c}\text { Megnevezés } \\
\text { Nettó jelenérték } \\
\text { (NPV) }\end{array}$ & Elvárt értékek & Eredmény \\
\hline $\begin{array}{c}\text { Belsö megtérülési } \\
\text { ráta (IRR) }\end{array}$ & IRR $>6 \%(\mathrm{r})$ & $\mathrm{NPV}=29264999 \mathrm{Ft}$ \\
\hline $\begin{array}{c}\text { Diszkontált } \\
\text { megtérülési idő } \\
\text { (DPB) }\end{array}$ & $\mathrm{DPB}>50$ év(t) & $\mathrm{DPB}=24$ év \\
\hline $\begin{array}{c}\text { Jövedelmezöségi } \\
\text { index (PI) }\end{array}$ & $\mathrm{PI}>1$ & $\mathrm{PI}=1,21$ \\
\hline
\end{tabular}

Forrás: Saját kalkulációs eredmények alapján, a szerzők szerkesztése.

A nettó jelenérték több, mint 29 millió Ft értéket mutatott, ami nagyobb, mint 0 , ez alapján a beruházás várhatóan növelni fogja a vállalkozás értékét. A belső megtérülési ráta értéke $9 \%$, ami nagyobb az elvárt hozamnál, tehát érdemes megvalósítani a projektet.

A diszkontált megtérülési idő értéke 24 év, tehát 24 év alatt fog a beruházás megtérülni. Mivel ez az érték kevesebb, mint a beruházás várható élettartama (50 
év), így ez a mutató is bizonyítja, hogy a beruházás meg fog térülni a hasznos élettartamon belül (Illés, 2009).

Végül a jövedelmezőségi indexet számoltuk, ami alapján minden befektetett $1 \mathrm{Ft}$ után 1,21 Ft jövedelem várható.

\section{Záró gondolatok}

Minden gazdaságossági mutatónk eredménye pozitív értékkel bír a beruházás megvalósításához, ezért megállapíthatjuk, hogy érdemes megkezdeni a gyümölcsfeldolgozó üzem létesítését.

Összességében megállapíthatjuk, hogy önerőből finanszírozva is gazdaságosan megtérül a beruházás az elvárt időn belül.

Jövőbeni kutatásaink során pályázati forrás bevonásával történő finanszírozás gazdaságosságát fogjuk vizsgálni, majd a kétféle szcenárió összehasonlítására is sor kerül.

Az eddigi és a további elökalkulációink alapján fogjuk meghozni a beruházás megvalósításával kapcsolatos döntéseinket. Hampel Györgyöt (2011) idézve: fontos, hogy jól megalapozott döntések szülessenek, legyenek azok a szervezet müködésének bármely területén, akár a pénzügyekről, a termelésről és a termelési tényezőkről vagy akár a kereskedelemről van szó, mindig a szervezet érdekeit szolgálják.

\section{Köszönetnyilvánítás}

A tanulmány az Emberi Erőforrások Minisztériuma UNKP-19-1 kódszámú Új Nemzeti Kiválóság Programjának, továbbá az Emberi Erőforrás Támogatáskezelő és a Nemzeti Tehetség Program NTP-HHTDK-19-0001 számú pályázat támogatásával készült.

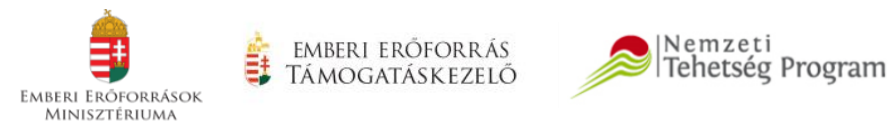

\section{Irodalomjegyzék}

Andrási Z., Borsi B., Farkas L., Némethné P. K., Papanek G., Viszt E. (2009): A mikro-, kis és közepes vállalatok növekedésének feltételei. GKI Gazdaságkutató Zrt., Budapest.

Bélyácz I. (2007): A vállalati pénzügyek alapjai. Aula Kiadó, Budapest.

Gál J. (2009): Fogyasztóvédelem az élelmiszergazdaságban. In: Gál J.; Gulyás L. (szerk.) Élelmiszeripari kis- és közép-vállalkozások fejlesztése, különös tekintettel a román és szerb piacra. Szegedi Tudományegyetem Mérnöki Kar, Szeged, 233-262.

Hampel Gy. (2011): Vezetői információk - felmérés a Dél-Alföld élelmiszeripari vezetőinek körében.

In: Laczka; Szenteleki, K (szerk.): Agrárinformatikai Tanulmányok II. Magyar Agrárinformatikai Szövetség (MAGISZ), Debrecen, 34-61.

Illés I. (2009): Vállalkozások pénzügyi alapjai. SALDO Pénzügyi Tanácsadó és Informatikai Zrt., Budapest.

Kanyó T., Miklay Jné., Taródi Mné. (2008) Zöldség- és gyümölcsfeldolgozás. Nemzeti Agrárszaktanácsadási Képzési és Vidékfejlesztési Intézet, Budapest.

Kis K. (2014): Vidékgazdaság, kultúra, lokalizáció: eltérő válaszok és fejlődési differenciák. Jelenkori társadalmi gazdasági folyamatok, 9 (1-2): 9-28. 
Kormos Z. (2017): A magyarországi zöldség- és gyümölcsfeldolgozás versenyképességének területi vizsgálata. Doktori értekezés. Debrecen.

Medina V. (2005): A magyar zöldség-gyümölcs ágazat vizsgálata és ágazati stratégiájának megfogalmazása. Doktori értekezés, Budapesti Corvinus Egyetem Gazdálkodástani Doktori Iskola Agrárközgazdasági Ph.D. Program, Budapest.

Turi, A., Goncalves, G., Mocan, M. (2014): Challenges and Competitiveness Indicators for the Sustainable Development of the Supply Chain in Food Industry. Challenges and Innovations in Management and Leadership. 12th International Symposium in Management, Procedia - Social and Behavioral Sciences, 20 March 2014, 11-12 October 2013, Timisoara, Romania. 124: 33141. 